\title{
BEATAS SOJUZGADAS POR EL CLERO: LA IMAGEN DE LAS MUJERES EN EL DISCURSO ANTICLERICAL EN LA ESPAÑA DEL PRIMER TERCIO DEL SIGLO XX
}

\author{
Ma PILAR SALOMÓN CHÉLIZ* \\ Universitat de València
}

Los estudios de género han puesto de manifiesto que las imágenes más perdurables de las mujeres en la época contemporánea las ligan a la maternidad y al cuidado del hogar, un patrón que acabó imponiéndose a lo largo del XIX y que respondía al esquema burgués de la domesticidad ${ }^{1}$. Esto se refleja, por ejemplo, en la escasez de protagonistas femeninos en las imágenes y fotografías relativas al primer tercio del siglo XX que se podían contemplar en las exposiciones celebradas en los últimos años para rememorar la historia de España en el siglo pasado, a no ser que la exposición tuviera un especial interés por la historia de las mujeres. En ese caso podían aparecer escenas que recordaban distintos aspectos de su vida cotidiana: trabajando en el campo o en la fábrica, lavando en el lavadero público, disfrutando de las fiestas populares confundidas entre el gentío, etc., en caso de ser mujeres de sectores populares. Si ocupaban un lugar más privilegiado del escalafón social, se retrataban presidiendo mesas benéficas, participando en labores caritativas o asistiendo a fiestas de sociedad. Independientemente de su adscripción social, las mujeres podían verse también en instantáneas de ceremonias religiosas, o a la entrada y salida del templo.

En los últimos años la historia cultural ha llamado la atención sobre la importancia de la representación, en especial por sus repercusiones en la construcción de identidades individuales y colectivas y por sus consecuencias en el terreno político. Los estudios han destacado que las identidades no se manifiestan unificadas, sino que aparecen fragmentadas, y que en su construcción interactúan

* La autora participa en el proyecto de investigación BHA2002-01073. Cuenta también con un ayuda de investigación postdoctoral de la Fundación Caja de Madrid.

1. Anderson, Bonnie y Zinsser, Judith: Historia de las mujeres: una historia propia, Barcelona, Crítica, 1991, vol 2; Duby, George y Perrot, Michelle (dirs.): Historia de las mujeres, Madrid, Santillana, 2000, vols. 4 y 5; GARRIDO, E. (ed.): Historia de las mujeres en España, Madrid, Síntesis, 1998.

Feminismo/s, 2, diciembre 2003, pp. 41-58 
y se entrecruzan, a menudo de forma antagónica, discursos y prácticas. Es éste un proceso histórico; o dicho de otro modo, las identidades están siempre en construcción y lo hacen desde dentro de las representaciones que se elaboran y difunden sobre dichos sujetos, no fuera de ellas. Se ha incidido igualmente en que en el discurso, las representaciones contribuyen tanto a definir al "otro", como a definir a uno mismo en función de la imagen construida del "otro». Y se ha resaltado que esas representaciones se configuran en un contexto marcado por el ejercicio de distintas formas de poder ${ }^{2}$. Siguiendo estos presupuestos, algunos trabajos han analizado, por ejemplo, cómo se construyen los hombres a sí mismos. Junto a cuestiones como el ejercicio de la autoridad en la casa, han resaltado que dicho proceso se configura también en una parte sustancial por oposición a la imagen que proyectan de las mujeres. Los estudios de género, por su lado, han incidido en las consecuencias que ello tiene en el ejercicio del poder en todos los ámbitos de la vida social, sin olvidar el político³.

El proceso de secularización experimentado por las sociedades europeas occidentales, incluida la española, en la época contemporánea parece haber ido acompañado de un proceso de feminización de la religión ${ }^{4}$. Hasta el punto de que la práctica religiosa continuada y el ejercicio de actividades caritativas llegaron a ser consideradas, desde finales del siglo XX, más propiamente femeninas que masculinas. Era ampliamente aceptado, incluso entre los sectores progresistas, que la religión contribuía a preservar la virtud de la mujer porque servía de freno a sus pasiones.

En España, esa vinculación femenina con la religión se convirtió en un arma arrojadiza contra las mujeres cuando, en octubre de 1931, las Cortes Constituyentes de la Segunda República debatieron y aprobaron el sufragio femenino. Se escucharon en el marco parlamentario ideas que delataban el profundo antifeminismo que, basado en presupuestos anticlericales, latía en amplios sectores republicanos y obreros. El hecho llama la atención si consideramos que el apoyo al feminismo en España ha procedido principalmente de la izquierda. Sin embargo, pone de manifiesto que, junto a un antifeminismo conservador de raíz católica, hubo un antifeminismo de izquierdas de base fundamentalmente anticlerical ${ }^{5}$.

2. Hall, Stuart: «Who needs identity?», en S. Hall y P. De Gay (eds): Questions of Cultural Identity, Londres, Sage, 1996, pp. 1-17, así como el libro editado por el primer autor, Representation. Cultural Representatios and Signifying Practices, Londres, Sage, 1997.

3. Butler, Judith: El género en disputa. El feminismo y la subversión de la identidad, México, Paidós, 2001. Nixon, S: «Exhibiting masculinity», en S. Hall (ed.): Representation..., op.cit., pp. 298-300; Mosse, George L.: La imagen del hombre. La creación de la moderna masculinidad, Madrid, Talasa Ediciones, 2000 .

4. Sobre esta cuestión y sus repercusiones en la escasez de estudios sobre la relación de las mujeres con la religión en sentido amplio, he llamado la atención en «Mujeres, religión y anticlericalismo en la España contemporánea: ¿para cuándo una historia desde la perspectiva de género?», en VVAA: El Siglo XX: balance y perspectivas, Valencia, Fundación Cañada Blanch, 2000, pp. 237-245.

5. Sobre el antifeminismo de ambas procedencias en Francia, véase BARD, Christine (ed.): Un siglo de antifeminismo, Madrid, Biblioteca Nueva, 2000. Para la relación del feminismo con la izquierda y el laicismo, véase SCAnlon, Geraldine M.: La polémica feminista en la España contemporánea (1868- 
Beatas sojuzgadas por el clero: la imagen de las mujeres en el discurso anticlerical en la España del primer tercio del siglo XX

Aunque no trascendieran al debate parlamentario hasta octubre de 1931, las ideas que entonces se escucharon se podían leer en la prensa republicana y obrera de orientación anticlerical cada vez que se publicaba un artículo relacionando mujer y religión, o mujer y clero. Igualmente, aunque con menor frecuencia, esas ideas se transmitían por medio de representaciones gráficas. Mucho más abundantes en la prensa obrera y republicana de comienzos de siglo que en los años treinta, escenificaban sobre todo una de las críticas más comunes que desde los medios anticlericales se le hacían al clero, su lujuria. ¿Cómo describían a las mujeres esas viñetas? Responder a dicha pregunta es el objetivo de estas páginas; pero, para ello, conviene analizar previamente cómo presentaba a las mujeres el discurso anticlerical que servía de base a las imágenes reproducidas en la prensa de signo anticlerical.

\section{SERES DOMINADOS POR EL CLERO: LAS MUJERES EN EL DISCURSO ANTICLERICAL ${ }^{6}$}

Los hombres pro-republicanos que escribían esos artículos periodísticos aparecían implícitamente como adalides del progreso y la razón, por oposición al clero y a las mujeres a las que -según aquellos-dominaba, a quienes se identificaba con la ignorancia, la superstición y el atraso. No era un discurso exclusivo de los sectores anticlericales españoles. Lo podemos encontrar también en la prensa republicana francesa de finales del XIX y comienzos del XX, y, de hecho, constituyó un argumento recurrente para negar el voto a las mujeres en la Francia de los años veinte y treinta ${ }^{7}$.

Ese discurso, aunque tenía en parte raíces populares muy antiguas -v.g., lo referido a la mujer como objeto de la lujuria del clero-, parece haberse configurado a finales del XIX, en el contexto de la crisis de fin de siglo. Las ideas de la decadencia de la raza y de la nación ampliamente difundidas en Europa occidental, por un lado, y la ruptura del papel tradicional de la mujer, por otro, con la ola de misoginia subsiguiente, tuvieron importantes repercusiones políticas, especialmente en Francia, de donde mamaba sus ideas el republicanismo español ${ }^{8}$. Varios indicios del discurso anticlerical apuntan en esa dirección: por ejemplo, las abundantes exaltaciones de lo varonil, ligado al progreso y a la

1974), Madrid, Siglo XXI, 1976; FAGOAGA, Concha: «La herenca laicista del movimiento sufragista en España", en A. Aguado (coord.): Las mujeres entre la historia y la sociedad contemporánea, Valencia, Conselleria de Bienestar Social, 1999, pp. 91-111, y diversos trabajos de Mª Dolores Ramos, por ejemplo: «La cultura societaria del feminismo librepensador en España (1895-1918)», en A. Quiles y T. Saurat (coords.): Prototipos e imágenes de la mujer en los siglos XIX y XX, Málaga, Universidad de Málaga, 2002, pp. 75-98.

6. En este apartado se reelabora parte de la comunicación «Mujer y anticlericalismo: persistencia de la imagen tradicional de la feminidad en el discurso masculino», Actas del Congreso Internacional Escritura y Feminismo, Icaria Editorial, III vol., (en prensa).

7. Offen, Karen: European Feminisms 1700-1950. A Political History, Stanford, Stanford University Press, 2000, p. 273; BARD, Christine (ed.): Un siglo de antifeminismo... op.cit., pp. 136-139.

8. De ese contexto escriben Caine, Barbara y Sluga, Glenda: Género e Historia. Mujeres en el cambio sociocultural europeo, de 1780-1920, Madrid, Narcea, 2000, pp. 111-171; Bock, Gisela: La mujer en la historia de Europa, Barcelona, Crítica, 2001, pp. 154-158, 209. 
razón, frente a la identificación con lo femenino de todo lo relacionado con la Iglesia y la religión; las referencias a las consecuencias negativas que tenía sobre la virilidad de la juventud la educación dada por las órdenes religiosas; la influencia atribuida a éstas en la decadencia de España, en concreto en la pérdida de las colonias; las duras acusaciones de abandonar sus obligaciones en el hogar que lanzaban contra las "beatas», entre las que incluían a las católicas militantes, cuyo número iba en aumento desde que a comienzos de siglo la Iglesia católica empezó a prestar atención a la movilización del laicado?.

La imagen de las mujeres que transmitía la ideología anticlerical del primer tercio del siglo XX nos remite a una sociedad patriarcal en la que la condescendencia y el paternalismo, cuando no un machismo explícito, eran las características que solían definir las actitudes masculinas ante las mujeres. La constatación de la presencia predominante de éstas en todo lo relacionado con el mundo de la religión había dado lugar a un estereotipo femenino que los medios anticlericales reproducían constantemente. A su juicio, la actitud de las mujeres ante la religión respondía siempre a la influencia subyugadora del clero, que las sugestionaba fácilmente. Su carácter débil y crédulo, sus excesivas inclinaciones religiosas y su falta de educación las convertían en seres especialmente vulnerables a la influencia del clero, prontas a caer en la superstición y el fanatismo.

Cuando se referían a las religiosas en particular, la imagen que presentaban de ellas respondía al concepto radicalmente negativo que los anticlericales atribuían a los conventos. Los artículos de la prensa de signo anticlerical hacían hincapié en la incompatibilidad entre el régimen de estricta clausura seguido por numerosas comunidades, sobre todo femeninas, y la libertad individual de las enclaustradas, quienes según los anticlericales no podían abandonar el convento ni en casos de excepcional gravedad -por ejemplo, la enfermedad o muerte de los padres. Esto los llevaba a clamar contra la desnaturalización de aquellas mujeres que, en contra del mandamiento del amor predicado por Cristo -decían-, eran incapaces de transmitir una mínima muestra de ternura como hijas. La fe en la bondad natural del hombre, común a todas las corrientes anticlericales herederas de las Luces, les llevaba a poner el acento no tanto en la maldad de las religiosas cuanto en la del propio régimen de clausura, al que calificaban de auténtico secuestro de las hermanas. El sistema de reclutamiento no dejaba dudas al respecto -decían-, pues muchas entraban siendo menores de edad, bien por presiones familiares, bien sugestionadas por el confesor, que actuaba movido por la belleza o la riqueza de las jóvenes ${ }^{10}$.

9. Gueva, Julio de la: «Católicos en la calle: La movilización de los católicos españoles (1900-1936)», Historia y política, 3 (2000), pp. 54-79; SAlomón, Ma. Pilar: Anticlericalismo en Aragón. Protesta popular y movilización política (1900-1939), Zaragoza, Prensas Universitarias de Zaragoza, 2002, pp. 41-61.

10. Tierra y Libertad, Barcelona, 21 de junio de 1902, recomendaba dos libros publicados por la Editorial Moderna de Madrid, Memorias de una monja y El manuscrito de una monja, para que las jóvenes vieran los horrores a que se exponían si se encerraban en un convento olvidando las ternuras y sentimientos de la vida. Ideas similares se difundían a través de la literatura, como la Novela Ideal de Urales, Federico: Sor María de la Cruz, Barcelona, Publicaciones de la Revista Blanca, 1936. 
Beatas sojuzgadas por el clero: la imagen de las mujeres en el discurso anticlerical en la España del primer tercio del siglo XX

La imagen de la mujer seglar, por su parte, se construía en relación con la del clero secular. Era su principal víctima, según los anticlericales: sobre ella ejercía su máxima aspiración, la de dominar las conciencias; y, además, era el objeto de sus deseos sexuales reprimidos por el voto de castidad. De ahí las recomendaciones a los padres y, sobre todo, a los maridos, previniéndoles contra el cura. Se avisaba a los hombres de las consecuencias de cualquier relación espiritual de sus mujeres con un clérigo, recordando reiteradamente que el marido que dejaba confesar a su mujer perdía toda autoridad en la casa. La caricaturización de esta máxima dio lugar a algún que otro cuento cuyo protagonista era un hombre bueno, pero débil de carácter, casado con la sobrina del cura y, por ende, símbolo supremo del marido sin autoridad en el hogar ${ }^{11}$.

No sólo se advertía de las inclinaciones sexuales del clero hacia las mujeres casadas, sino también de la táctica clerical de controlar e influir en la conciencia del hombre a través de su esposa. El discurso anticlerical achacaba a la mujer un papel muy importante al servicio de la opresión socio-ideológica clerical, hasta el punto de que, en algunas ocasiones, planteaba que muchos hombres no sólo se veían obligados a fingir inclinaciones católicas por miedo a ver cerrado el camino del éxito social o profesional, sino, sobre todo, por miedo a las mujeres. Y, junto a esta crítica, la más común de atribuir a la influencia de sus esposas claudicaciones privadas de muchos individuos que en público blasonaban de anticlericales.

En manos de la teocracia -se decía-, la mujer abandonaba con criminal indiferencia al hombre, aprendía a aborrecer la libertad e independencia de la conciencia humana como algo pecaminoso y, en definitiva, se convertía en una rémora para el progreso humano, comenzando por su propio hogar. Allí, siguiendo las instrucciones aprendidas del confesor, intentaba ajustar la vida de la familia -relación conyugal, educación de los hijos, etc.- a las disposiciones e intereses clericales; intentaba incluso condicionar el voto y las ideas de su marido, actuando como correa de transmisión de la voluntad clerical de su confesor. En palabras de Zola, la mujer seguía siendo la «bestia de lujuria» de que únicamente se servía el sacerdote "para afianzar el reino de la Mentira» ${ }^{12}$.

Según los anticlericales, el hogar no era el único campo de actuación de las mujeres al servicio del enemigo clerical, especialmente cuando eran ricas y de buena posición social. Ejercían la caridad privada con fines proselitistas, hacían el vacío en público a las pocas mujeres distinguidas que no seguían los dictados clericales, u organizaban actos y comisiones para influir en la opinión pública a favor de leyes de matiz confesional o en contra de las anticlericales. A comienzos de siglo, este tipo de actuaciones fue denunciado con motivo de la campaña

11. Como el caso de Homobono, protagonista apocado del cuento de MeLié, Juan A.: Fía en Dios, Madrid, Imprenta Calleja, 1909.

12. Cita de Zola en "La mujer y el voto», La Tierra, Madrid, 28 de noviembre de 1933. De la actitud de dicho escritor ante las mujeres, escribe PERROT, Michelle: «Es Émile Zola un antifeminista? Una lectura de "Fecundidad» (1899)", en C. Bard (ed.): Un siglo de antifeminismo... op.cit., pp. 79-92. 
en favor del descanso dominical. Pero alcanzaron su mayor apogeo durante la Segunda República ante acciones como la recogida de firmas contra la expulsión de las órdenes religiosas, el lucimiento de crucifijos en el pecho en señal de protesta por la legislación anticlerical, las visitas domiciliarias a mujeres para convencerlas del daño que la República suponía para la religión, la participación activa en rogativas por la Iglesia y por España, etc. Frente a estas actividades que desarrollaban las mujeres, los anticlericales reaccionaban de forma machista, incluso misógina: las atribuían, de forma peyorativa, a arrugadas e histéricas beatas o a jovencitas desocupadas; y clamaban contra el clero porque, reformando lo preceptuado en el Evangelio -aseguraban-, ensalzaba «la rebeldía de la mujer, que sin permiso del marido va a la Iglesia, abandonando casa y familia» ${ }^{13}$.

Con todo, la mayor explosión del anticlericalismo machista y misógino llegó al aprobarse el sufragio femenino en octubre de 1931. A juzgar por la furia antifeminista del anticlericalismo republicano, la participación directa y activa de las mujeres en la política por medio del voto corría el peligro de multiplicar perniciosamente las consecuencias de la influencia clerical. Esta ya no sería ejercida indirectamente por medio de sutiles presiones de la mujer sobre su marido -se aseguraba-, sino de forma directa, pues el electorado femenino iba a obedecer ciegamente las exigencias de la jerarquía, recelosa del nuevo régimen. El voto de la mujer amenazaba con extender a la esfera del poder público la perturbación que el clero introducía en el hogar. En definitiva, la mujer, además de ser «instrumento de sus concupiscencias», lo era también «de sus cálculos mercenarios» en el terreno político ${ }^{14}$.

Como consecuencia de todo ello -argumentaban los anticlericales-, la aprobación del sufragio femenino no iba a fortalecer la República, sino que se volvería contra ella. Insistían en que hubiera sido más razonable retrasar la concesión del voto a las mujeres, hasta que adquirieran una mayor educación que les permitiera desmarcarse del yugo clerical ${ }^{15}$. Votaran a favor o en contra del sufragio femenino, todos los grupos republicanos y obreros anticlericales lo miraron con cierto recelo a medida que se aproximaban las elecciones de noviembre de 1933, la primera vez que participaba la mujer en unos comicios generales. Sin embargo, no todos lo interpretaron por igual: entre los republicanos primó el discurso de género; entre la izquierda obrera, el de clase.

Para los primeros, la visión negativa del voto femenino abarcaba a todas las mujeres sin distinción; o, si no, a la gran mayoría de ellas, porque estaban subyugadas por el clero y seducidas por la campaña en defensa de la Iglesia amenazada por la República. A la vez que hablaban de la necesidad de educar a la mujer y de las ventajas que el nuevo régimen le había reportado frente a siglos de sumisión clerical, los más reacios exponían un discurso antifeminista

13. «Vamos progresando...», El Progreso, Zaragoza, 16 de diciembre de 1904, p.1.

14. "El voto de la mujer», El Radical, Zaragoza, 16 de octubre de 1933.

15. Sobre los debates parlamentarios en torno a la concesión del sufragio femenino, véanse ARBELOA, Víctor M: La Semana Trágica de la Iglesia en España (1931), Barcelona, Galba Edicions, 1976, pp. 46-52, y SCanlon, Geraldine M.: La polémica feminista... op.cit., pp. 274-278. 
Beatas sojuzgadas por el clero: la imagen de las mujeres en el discurso anticlerical en la España del primer tercio del siglo XX

que rayaba en el desprecio hacia el voto femenino. Detrás de ello, parecía que había un intento por distanciarse de su propio fracaso como hombres a la hora de orientar el voto de sus mujeres, derecho que creían tener como maridos o como padres ${ }^{16}$. Sólo algunos artículos de la prensa republicana furibundamente anticlerical mencionaban el voto de la mujer obrera como tabla de salvación de la República. Esa imagen respondía al mito de la mujer trabajadora que se valía por sí sola y que sabía lo difícil que era luchar por la vida; en definitiva, al mito de la dolorosa que estaba junto al obrero luchador, que creía y confiaba en él.

Esas pinceladas se convertían en el centro del mensaje socialista orientado a captar el voto femenino. En un discurso claramente clasista diferenciaba el voto de la mujer burguesa, apoyado en la tradición clerical, del de la proletaria, conocedora de las injusticias sociales del orden capitalista -se decía-. Las elecciones se planteaban así como un nuevo marco de la lucha obrera, en el que la mujer debería continuar su tradición de solidaridad y de lucha al lado del hombre en favor de la emancipación del proletariado, porque, en definitiva, con ella lograría la suya. Como proletaria -se aseguraba-, sabía que la Iglesia había legitimado el orden capitalista represor y explotador; además, al igual que su marido o sus hijos, hacía tiempo que se había alejado de las patrañas predicadas por el clero. Por tanto, era imposible que acabara votando a las derechas apadrinadas por el ejército clerica ${ }^{17}$. Con todo, este mensaje estaba lejos de representar una versión feminista del anticlericalismo, pues no apelaba al voto de la mujer en función de consideraciones ideológicas sobre sus propios derechos, sino en referencia a los de su marido, su padre o sus hijos como proletarios.

Todo ello no obstaba para que los socialistas, junto con todos los demás sectores anticlericales, reclamaran la necesidad que tenía la mujer de recibir una educación que le permitiera dejar de ser un instrumento en manos del clero, al servicio de su afán de control ideológico de la sociedad. En este sentido, los altos índices de analfabetismo ofrecían un argumento incontestable y cómodo al anticlericalismo, que en ningún momento se paró a pensar en otras posibles claves explicativas de la vinculación de muchas mujeres a la Iglesia.

Según el discurso anticlerical, la relación que una mujer establecía con su confesor reflejaba perfectamente la imagen de ser inferior carente de educación. El confesionario era para los anticlericales el símbolo por antonomasia de

16. Esto es lo que se deduce de las palabras de Torrubiano, Jaime: Política religiosa en la democracia española, Madrid, Sucesores de Rivadeneyra, 1933, p. 37. Un ejemplo del desprecio por el voto femenino en "El voto electoral de la mujer», La Tierra, 14 de octubre de 1933, donde se opone el voto de la mujer «señora», de honor templado, que jamás traicionaría la voluntad de su marido ni la de sus hijos, al de las "señoritas», "aquellas que se 'inician' en casi todos los misterios en las sacristías y en los cabarets -es lo mismo-».

17. Esa visión de la mujer que ofrecía la prensa socialista podía responder a un objetivo propagandístico de cara a las elecciones, pero constituía un lugar común bastante aceptado, incluso fuera del partido socialista; SCANLON, Geraldine M: La polémica feminista..., op.cit., p. 277. Escepticismo anarquista al respecto en El Porvenir del Obrero, 25 de octubre de 1902, "Influencia del clericalismo en la mujer»; La Revista Blanca, 1 de mayo de 1901, "El triunfo»; El Productor, 14 de marzo de 1903, "Pensad mujeres»; 25 de abril de 1903, "Oid esclavas»; Tierra y Libertad, 6 de agosto de 1913, «¿Cómo desterrar las ideas religiosas del cerebro femenino?». 
la aspiración que movía al clero a dominar las conciencias de los individuos. Representaba, además, el lugar donde se mostraba de forma privilegiada la debilidad de aquél por el sexo, ya que era una vía de acceso a las mujeres propia y exclusiva del clero ${ }^{18}$. Estas quedaban convertidas, en consecuencia, en mero objeto sexual en el que el clero volcaba sus deseos reprimidos. A partir de ahí se derivaban unas quejas anticlericales, casi exclusivas de los hombres, en las que había evidentemente parte de envidia machista, pero también mucho de honor herido en lo más preciado de su identidad masculina: la virilidad, elemento cultural típico de las sociedades latinas.

En conjunto, el tema de la mujer aparecía en el discurso anticlerical en función del clero secular, de sus aspiraciones de control sobre las conciencias y de sus irrefrenables deseos sexuales. Esta es la prueba más contundente y curiosa a la vez de la visión machista, a veces misógina, que dominaba en la ideología anticlerical, pues las relaciones clero/mujer quedaban siempre bajo la sospecha del favor sexual.

\section{LA MUJERES EN LA ICONOGRAFÍA ANTICLERICAL}

Como otros aspectos de la ideología anticlerical, la opinión sobre las mujeres se transmitía igualmente a través de representaciones gráficas. Esto resulta especialmente evidente en la prensa de orientación anticlerical de la primera década del siglo XX. Por entonces, la fotografía se estaba introduciendo en la llamada prensa de empresa, la que contaba con mayores medios económicos, pero no en los órganos periodísticos de partidos republicanos y obreros. Estos, siguiendo una tradición configurada a lo largo del XIX, recurrían a viñetas o a caricaturas para plasmar gráficamente contenidos críticos que se difundían habitualmente en sus páginas ${ }^{19}$. Dado el alto índice de analfabetismo existente entre las capas populares, la prensa republicana y obrera tenía en el dibujo un poderoso instrumento con el que propagar sus postulados ideológicos entre sus potenciales clientes. Por la abundancia de ilustraciones que aparecían en el periódico anarquista Tierra y Libertad (Barcelona) y en el de tendencia republicana La Traca (Valencia), hemos elegido algunas de contenido anticlerical publicadas en dichos medios para seguir este apartado.

El retrato que ofrecían de las mujeres las viñetas y caricaturas anticlericales se ajustaba a las ideas que de ellas se transmitían a través del discurso anticlerical. Se trataba, sobre todo, de caricaturizar la maldad atribuida al clero o las situaciones en que ésta se manifestaba más claramente. De ahí que la mujer no fuera normalmente la protagonista de la escena, sino una figura más bien secundaria que aparecía subordinada al clérigo representado. Lo que importaba del personaje femenino era precisamente su condición de mujer. Su imagen solía

18. Ávarez Junco, José: El Emperador del Paralelo. Lerroux y la demagogia populista, Madrid, Alianza Editorial, 1990, p. 403.

19. Un análisis general del desarrollo de la caricatura y la ilustración como representación de la realidad en Bozal, V.: El siglo de las caricaturas, Col. Historia del Arte n 40, Madrid, Historia 16, 1989. 
Beatas sojuzgadas por el clero: la imagen de las mujeres en el discurso anticlerical en la España del primer tercio del siglo XX

CONTRASTE

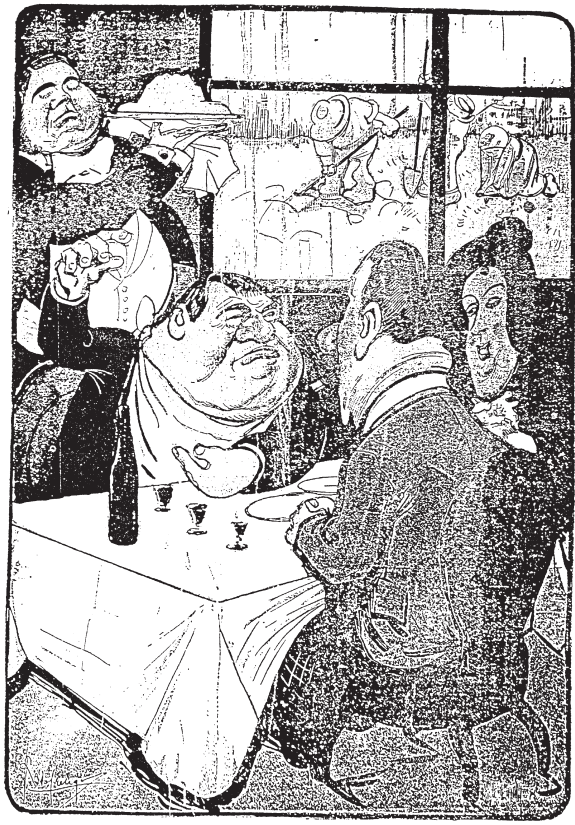

Ellos trabajan para nosotros, nosotros rezamos para ellos, y todos nos ayudamos mutuamente.

Figura 1: Tierra y Libertad, 29 de abril de 1904
EL BUEN CONSEJO

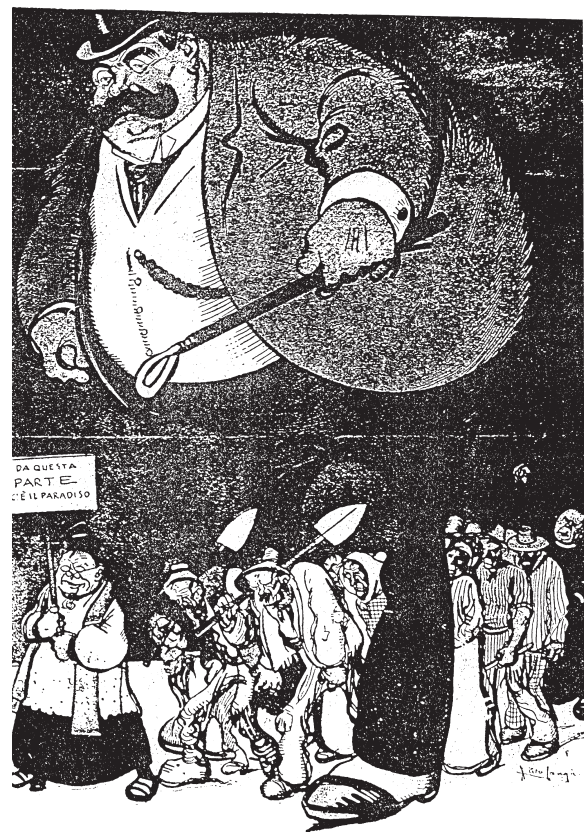

Así, así; obedeced y seguid a los ministros del Señor, que ellos os conducirán al camino que... a ellos y a mí nos conviene.

Figura 2: Tierra y Libertad, 21 de octubre de 1904

ser, en consecuencia, bastante indefinida desde el punto de vista social, excepto en aquellos casos en que la escena requería una protagonista burguesa de buena posición y de economía desahogada.

Cuando la viñeta transmitía una crítica anticlerical de contenido social -v.g., la denuncia del clero que vivía a costa del pueblo explotado-, la mujer, en caso de aparecer, siempre lo hacía en segunda fila. Si pertenecía a las clases trabajadoras, se divisaba confundida entre la masa informe del pueblo, avejentada y cargada de espaldas como símbolo de la obrera sufriente, contrapunto femenino del trabajador explotado (Figura 2). Si era una mujer de la burguesía, se la representaba en segundo plano, detrás del marido, acompañándolo y disfrutando con él y con algún clérigo de los placeres de una vida holgada (Figura 1).

De todos modos, en la mayoría de las ocasiones en que se dibujaba a una mujer, la escena tenía por objeto denunciar la perversión sexual que los anticlericales atribuían al clero. En ese caso, la mujer aparecía como objeto de la concupiscencia del clérigo correspondiente. No importaba tanto caracterizarla por su adscripción a una u otra clase social; lo que solía definir a las mujeres 


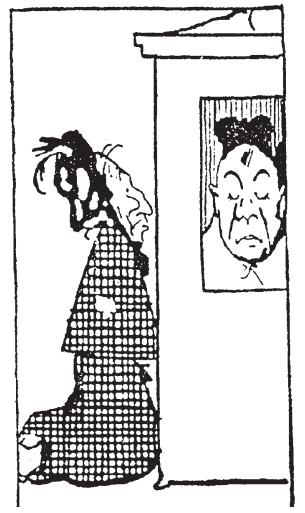

¡Gran pecado; muy gran pecado!

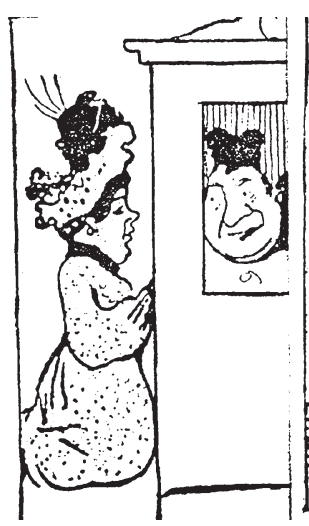

Sí, un desliz, un ligero desliz.

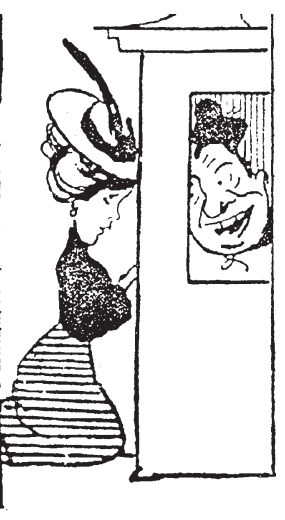

¡Ah, caramba, caramba! Cuidado, cuidado.

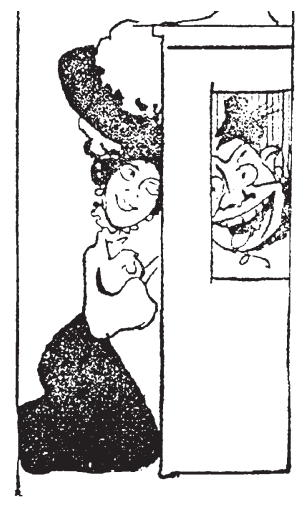

- ¿Y era guapo? - Muy guapo.

- Eso no es pecado; creced y multiplicaos, ¿se acuerda usted?

Figura 3: Tierra y Libertad, 6 de noviembre de 1903

era su edad, para ejemplificar con ella la actitud lujuriosa del clero. Se las solía representar como seres dependientes, carentes de voluntad ante él, para simbolizar así a la mujer sojuzgada y dominada por el clero.

La confesión, como ya hemos visto, era el momento más deplorado por los anticlericales por la intimidad que permitía entre el confesor y las feligresas y constituía una de las situaciones predilectas de las viñetas cuando se pretendía denunciar las debilidades sexuales del clero. Muy significativas al respecto resultan las imágenes de Tierra y Libertad en que se ridiculizaba el comportamiento y la flexibilidad moral del clero según cuál fuera la edad de las católicas que confesaba (Figura 3). Como en muchas de las imágenes de contenido anticlerical, el contraste entre las diferentes escenas o partes de una escena y los comentarios a su pie añadían significado a la crítica gráfica al clero ${ }^{20}$.

A la mujer vieja, magra y arrugada, arquetipo de la beata desde la perspectiva anticlerical, el cura no le presta ninguna atención en la confesión y sobre ella aplica el máximo rigor moral. Frente a esa estampa, el cura va demostrando un mayor interés y relajando sus juicios morales cuanto más joven y atractiva es la mujer al otro lado de la celosía. Enseguida se adivina por los comentarios de las viñetas que los pecados confesados por las mujeres más jóvenes hacen alusión al sexto o al noveno mandamientos. Cuando la mujer, que se supone casada, es atractiva, el cura la amonesta, no la censura; pero a la vez demuestra curiosidad insana por lo que le cuenta. Si la mujer es una joven soltera, autoriza

20. Lily LitvaK analiza los recursos utilizados por las publicaciones anarquistas a la hora de caracterizar al clero, entre otros colectivos considerados enemigos del pueblo, en Musa libertaria. Arte, literatura y vida cultural del anarquismo español (1890-1913), Barcelona, Antonio Bosh editor, 1981, pp. $45-61$. 
Beatas sojuzgadas por el clero: la imagen de las mujeres en el discurso anticlerical en la España del primer tercio del siglo XX

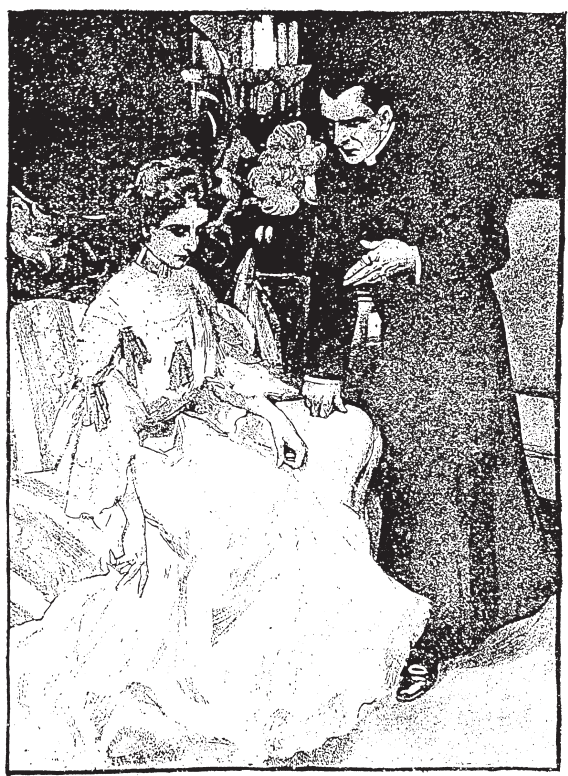

-El traje no está reñido con el amor... a todas las criaturas y usted es muy angelical, Lola. - ¡Que puede venir mi marido! -Le bendiciré, le bendiciré y le haré salir, porque la confesión no permite la presencia de terceros.

Figura 4: Tierra y Libertad, 9 de mayo de 1904 lo que según la religión católica es pecado y, además, manipula la doctrina para legitimarlo. La crítica anticlerical insinuaba con ello que el clérigo había dejado abierta la puerta para justificar cualquier avance deshonesto por su parte ante la joven.

Cuando la mujer casada, además de ser relativamente joven, era rica, la misma escena se representaba en un ambiente muy diferente (Figura 4). Ya no aparecen en el confesionario, sino en la lujosa casa de la señora; ella no está arrodillada, sino sentada; y el confesor, de pie, no sólo como signo de deferencia social ante la dama, sino en un intento de convencerla de la bondad de su proposición amorosa. La mujer, en este caso socialmente caracterizada por su adscripción a la alta burguesía -casa lujosa, sentada ante el clérigo en pie, ricamente ataviada-, permanece cabizbaja y en actitud sumisa, como incapaz de rebelarse y oponerse a los manejos del confesor. Dada su pose, sólo parece capaz de balbucir un tímido "¡Que puede venir mi marido!».

Otras viñetas denunciaban la concupiscencia del clero en situaciones diferentes a la de la confesión: por ejemplo, en la visita a un museo (Figura 5) o cuando tomaba algo en un restaurante, si lo atendía una camarera joven (Figura 6). En esta última, la mujer, una trabajadora, no aparece representada de forma tan sumisa como la anterior. El diálogo al pie de la viñeta denota que la camarera ha tenido voluntad de esquivar al clérigo -quien, ante la negativa, se dedica a repasar minuciosamente la cuenta; además de criticar la lujuria del clérigo, el dibujo caricaturiza su avaricia-. Esa actitud de la joven trabajadora representaba la esperanza que el discurso anticlerical obrerista expresaba de vez en cuando sobre la posibilidad de que la mujer obrera acabara emancipándose de la influencia clerical, por su misma condición de clase explotada, alejada progresivamente del clero.

El tema de la lujuria del clero fue el único que siguió apareciendo en la prensa, si nos atenemos a las viñetas publicadas por La Traca, una vez que el anticlericalismo dejó de estar presente en el debate público. Se dibujaba a las mujeres como objeto de la concupiscencia del clero, lo que llevaba a acentuar de forma caricaturesca sus rasgos sexuales característicos, dado el tinte satírico de dicho 
ESTETICA CLERICAL

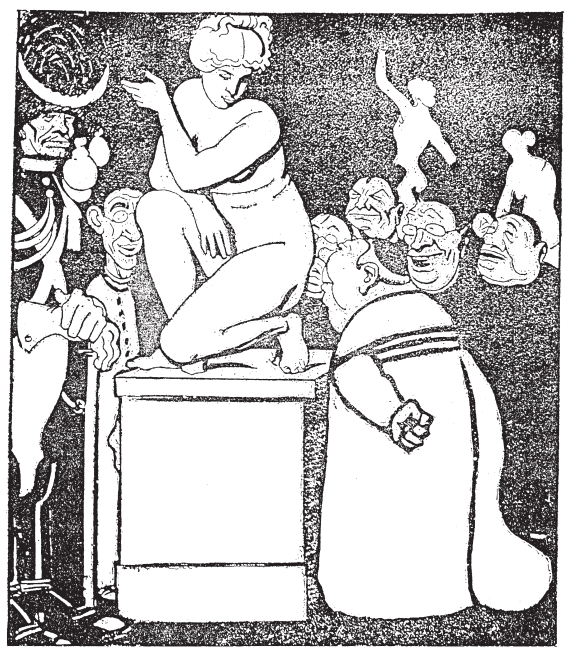

-Lo mejor y más bonito está por ese lado.

Figura 5: Tierra y Libertad, 18 de febrero de 1904 semanario. Por sus particulares vínculos con el clero, dos «tipos» de mujeres eran especialmente susceptibles de representación: las amas de los curas y las beatas, cuya imaginería seguía unos estereotipos bien definidos: abuelas arrugas y magras; mujeres maduras, entradas en carnes; y mujeres todavía de buen ver, que habían sufrido algún "desengaño amoroso» o eran viudas «frescas y de buen ver»" ${ }^{21}$.

Dichos estereotipos continuaban vigentes en los años treinta. Aunque en los dibujos siguió predominando la insinuación sobre la inclinación sexual del clero, la nueva situación política y el fin de la censura de prensa posibilitaron la aparición de contenidos más diversificados con claras implicaciones políticas. Así, por ejemplo, el ama del cura ya no es una mujer que atiende

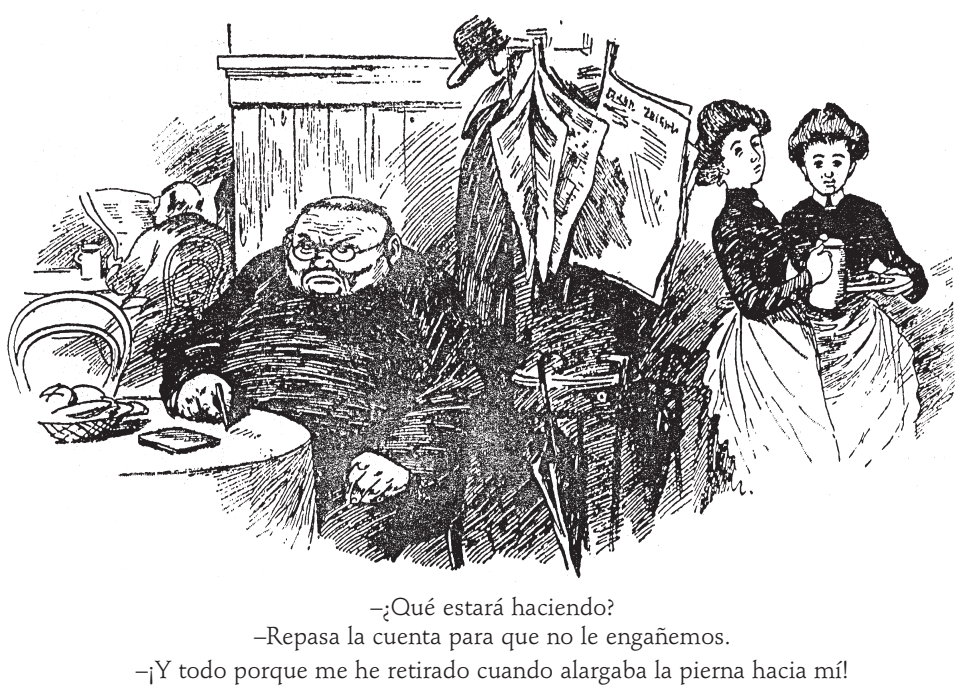

Figura 6: Tierra y Libertad, 9 de noviembre de 1904

21. La Traca, 26 de junio de 1920, sobre las amas de los curas. El 4 de marzo de 1921 se refería a las beatas. 
Beatas sojuzgadas por el clero: la imagen de las mujeres en el discurso anticlerical en la España del primer tercio del siglo XX

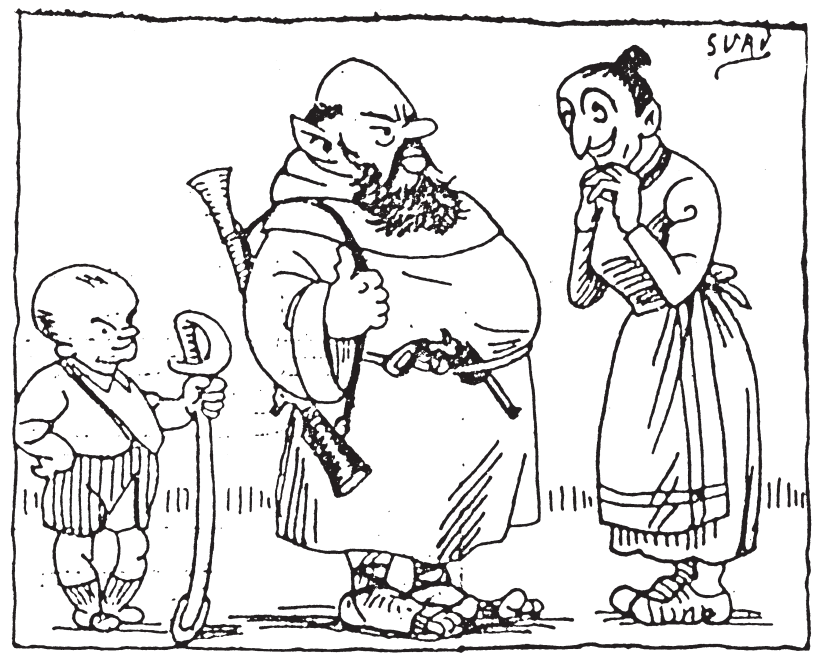

-¡Ay, Recaredo! Cuando te vea Segura tan armado, te nombra general.

-Más que general. Y sabes que me tiene gran preferencia.

Figura 7: La Traca, 11 de julio de 1931

a todas las necesidades del clérigo para el que trabaja; lo apoya también en su actitud militante contra la República (Figura 7). Aunque ningún detalle de la imagen de dicha mujer sugería voluptuosidad, la presencia del niño armado en la viñeta denota la relación sexual entre ama y cura.

Con todo, el sufragio femenino se convirtió en el principal punto de denuncia de las implicaciones políticas que, desde la perspectiva anticlerical, tendría el supuesto sojuzgamiento de las mujeres al clero. En octubre de 1931, cuando se aprobó el artículo relativo al sufragio femenino en la Constitución, la portada de La Traca presentaba un dibujo a toda página de un cura gordinflón con cara de cerdo, rodeado de mujeres a las que conminaba a usar su nuevo derecho en contra de la República (Figura 8). Las cinco figuras femeninas, ordenadas por edad, respondían a los estereotipos con que la prensa de signo anticlerical representaba a las mujeres: desde las ancianas más o menos enclenques y arrugadas hasta la joven voluptuosa endomingada - precisa-

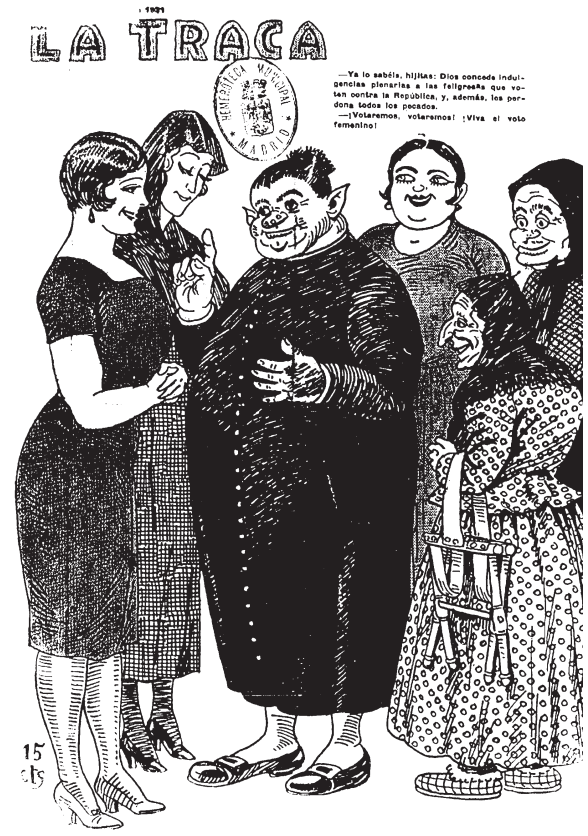

-Ya lo sabéis, hijitas: Dios concede indulgencias plenarias a las feligresas que voten contra la República, y, además, les perdona todos los pecados.

- Votaremos, votaremos! ¡Viva el voto femenino!

Figura 8: La Traca, octubre de 1931 


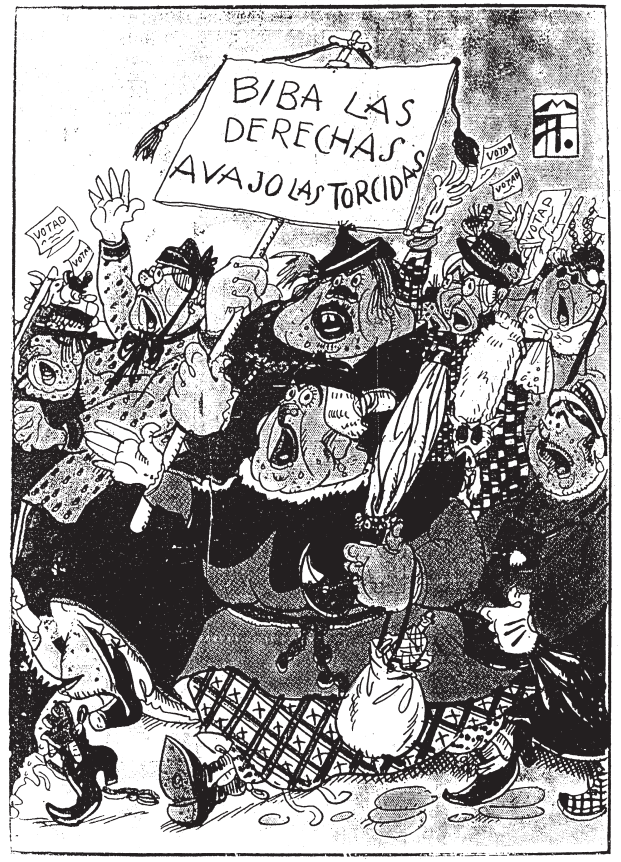

PROPAGANDA ELECTORAL DE DERECHAS

Esta colección de damas "birrias», se asemejan a un parque Zoológico, donde entran toda clase de fieras y todas éstas electorales, llevando dentro Panteras, leones, urracas, kakatuas, cotorras, loros, etc.

Figura 9: La Traca, noviembre de 1933 mente a la que se dirige el cura-, pasando por la señora gorda de edad más o menos madura y la otra más joven, piadosa y recatada, con velo y medias negras. Eran clichés que simbolizaban a las mujeres en general, sin preocuparse especialmente por su adscripción social. El único elemento en este sentido podría ser el calzado, pero el hecho de que las diferencias en este aspecto coincidan con la edad (zapatillas, la señora más vieja; zapatos, las dos más jóvenes) sugiere que, más que mujeres de clase media, se trata de señoritas arregladas para acudir a la iglesia.

Los estereotipos de las beatas se convirtieron en sangrantes caricaturas sobre la militancia católica femenina con la campaña electoral de noviembre de 1933. En la contraportada de uno de los números de dicho mes (Figura 9), otra imagen a toda plana ridiculizaba una manifestación de mujeres católicas en demanda del voto a la derecha. A modo de procesión caótica, la marcha iba encabezada por una pancarta llena de faltas de ortografía básicas, que recordaba a los estandartes de las cofradías en las procesiones, rematada por una cruz y adornada con cordones y borlas. Las mujeres, gritando, parecen un cruce de beatas y sufragistas: además de la pancarta con la cruz y algún que otro escapulario, en esta viñeta todas las mujeres llevan vestidos largos como las sufragistas -el tipo de bolso de la primera mujer es revelador al respecto- $y$ los zapatos y sombreros remiten a una clara adscripción de clase media. Todas son de mediana edad o mayores y, además de incultas, dan la apariencia de brutas, con un aspecto totalmente alejado del ideal de modernidad y de feminidad (feas, mal arregladas, vociferantes y dando pasos demasiado largos para una dama) y de modernidad. En realidad, parecen bestias: aparte de tener cara de animales (cerdos o urracas básicamente), algunos de los complementos que llevan actúan como símbolos de esa idea: los dos paraguas que terminan en forma de cotorras o loros, o la piel de (¿zorro?) que lleva una señora al hombro. Por si quedaban dudas, la nota al pie de la viñeta abundaba en la animalización de dichas mujeres. El contrapunto a estas beatas-sufragistas lo ofrece otro de los estereotipos de la votante de derechas, que correspondía a la mujer más o 
Beatas sojuzgadas por el clero: la imagen de las mujeres en el discurso anticlerical en la España del primer tercio del siglo XX

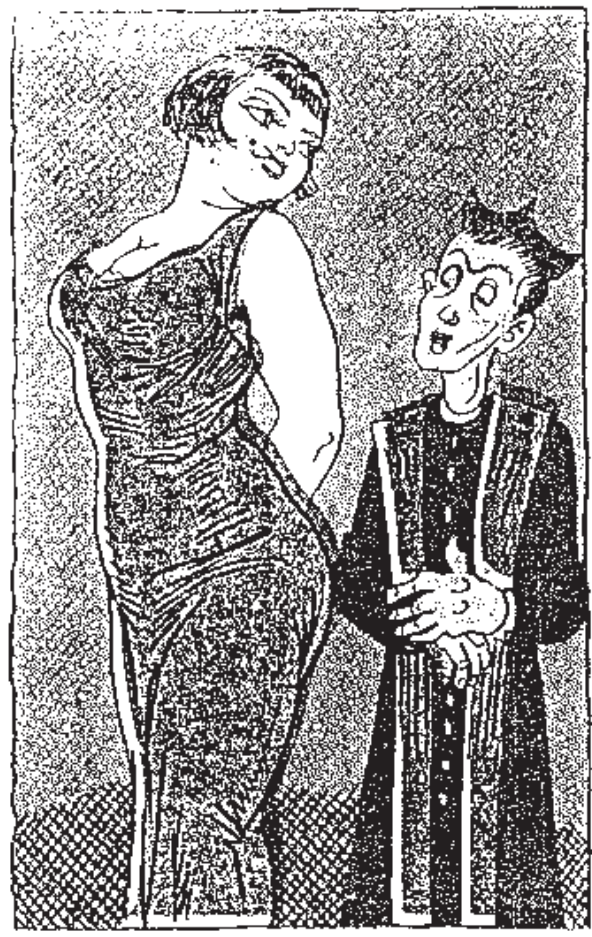

Ella

-Ha llegado el momento de votar las derechas. El aspirante cura -

¡Indecente, más que indecente!

Figura 10: La Traca, noviembre de 1933 menos joven, provocativa, con ropas ajustadas, una imagen que remitía a los comentarios anticlericales que cuestionaban su honestidad (véase, por ejemplo, el de la nota dieciséis) (Figura 10).

Sólo en una ocasión encontramos entre los gráficos de La Traca alusivos al sufragio femenino una escena diferente: la de una mujer, en esta ocasión claramente caracterizada de clase media, moderna y culta -lee un libro sentada en un banco-, que, en contra de las previsiones del cura que se acerca a ella, rechaza su propuesta de votar a la derecha (Figura 11). Actúa entonces como si le hubiera hecho una proposición indecente, golpeando al clérigo con el paraguas y dándole un puntapié sin perder su compostura femenina. La escena, sin embargo, quedaba contrarrestada por un artículo que ocupaba la otra mitad de la página bajo el título "Damas de estropajosa», en el que se calificaba a "la mujer española» de peligro para la República que iba a votar "como el ganado, a donde el pastor les lleva».

En resumen, desde la perspectiva anticlerical, el pensamiento y los anhelos femeninos parecían no existir más que en función del clero que los educaba, dirigía y controlaba. Aunque el objeto de las críticas fuera el clero, el discurso anticlerical transmitía una imagen muy negativa de las mujeres, que las representaciones gráficas se encargaban de rubricar. Aquéllas quedaban reducidas a meros peones del clero en su esfuerzo por controlar la moral de la sociedad. A pesar de los llamamientos en favor de la emancipación de la mujer a través de la educación, el interés real demostrado por los anticlericales en esta labor distó mucho de resultar ideal ${ }^{22}$. Aunque es un tema todavía

22. Uno de los innumerables manifestaciones en favor de la educación de la mujer aparece en MAGalhaes Lima, Sebastiao: Conferencia leida en el Ateneo de Madrid a invitación de la Liga Anticlerical, Madrid, Gran Oriente Español, 1912, pp. 21 y ss. Sobre el papel de las mujeres en el ámbito educativo de las escuelas laicas en Valencia, así como sobre las prácticas y representaciones de las identidades masculina y femenina en el blasquismo, escribe SANFeliu, $M^{a}$ Luz:, Republicanismo y modernidad. El blasquismo (1895-1910). Proyecto politico y transformación de las identidades subjetivas, Tesis doctoral (inédita), Dpto. Història Contemporània, Universitat de València, 2002. 
fi veces las apariencias... o la mujer extremista

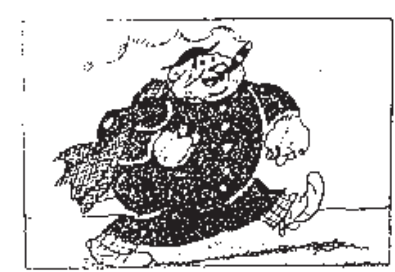

1. - Ahora derechito a cazar votos.

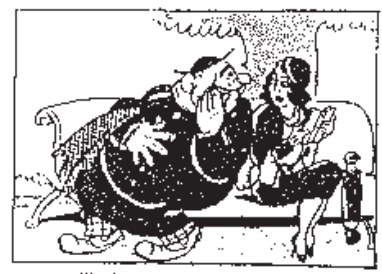

4. -¡Oh hermana! Usted será.. de «religión, familia, orden... y panza contenta..., y, por consiguiente, su voto...

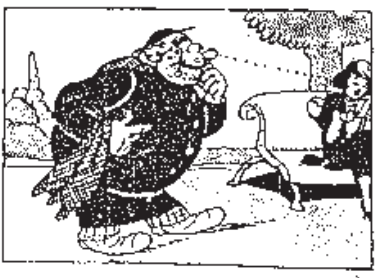

2. -¡Caramba, qué feligresa! Vamos a trabajarla...

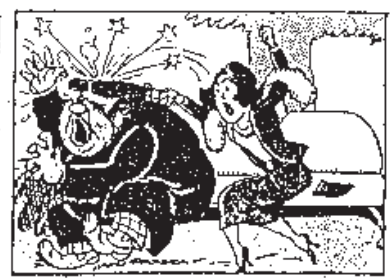

5. - ¡Yo soy de estacazo y tente tieso!...
Por Mendez Alvarez

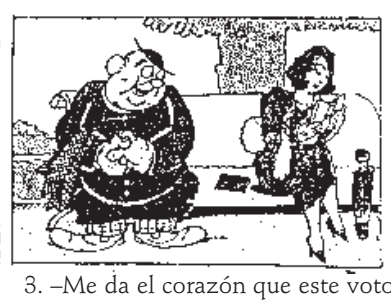
es seguro. Su cara es de ángel...

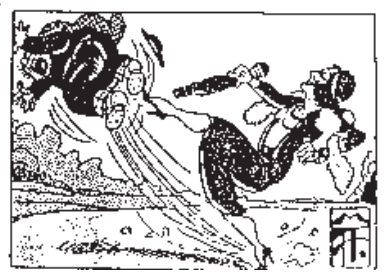

6. -¡Conque largo de aquí, pajarraco!...

Figura 11: La Traca, noviembre de 1933

por investigar, el contraste entre el discurso y la praxis en esta cuestión se hizo especialmente evidente durante la Segunda República. En esos años, parece que fue mucho más efectiva la movilización de las mujeres por los sectores conservadores, que apelaban a la defensa de la religión, identificada con la defensa de la familia y del orden, supuestamente amenazados por la República ${ }^{23}$. Los grupos republicanos no parece que fueran tan activos a la hora de educar y movilizar políticamente a las mujeres - ¡acaso daban por perdida la batalla?-. Eso sí, en ocasiones alababan a las militantes republicanas a través de sus órganos de prensa, exaltando sus virtudes como mujeres con gracia, rebeldes, estudiosas, partidarias del progreso y de la educación, en contraposición a las encuadradas en organizaciones católicas, a quienes se despreciaba calificándolas de mujeres con mala cara y $\sin$ quehaceres, que no aprendían nada bueno de la Iglesia, más que a rezar ${ }^{24}$.

23. Véase Vincent, Mary: "The Politicization of Catholic Women in Salamanca, 1931-1936», en F. Lannon y P. Preston (eds.): Elites and Power in Twentieth Century Spain, Oxford, Clarendon Press, 1990, pp. 107-126; con respecto a Aragón, SALOMÓN, Mª Pilar: «La movilización política de las mujeres católicas en Aragón durante la II República», en I. Peiró y P. Rújula (coords.), En construcción. Historia local contemporánea, Zaragoza, Centro de Estudios Darocenses, Institución Fernando el Católico, 2003, pp. 323-336. Blasco Herranz, I., Paradojas de la ortodoxia. Política de masas y militancia católica femenina en España (1919-1939), Zaragoza, Prensa Universitaria de Zaragoza, 2003.

24. «Coplas», El Radical, Zaragoza, 23 de enero de 1933. La movilización de las mujeres por la izquierda en los años treinta es un tema poco estudiado. Un estudio pionero a este respecto 


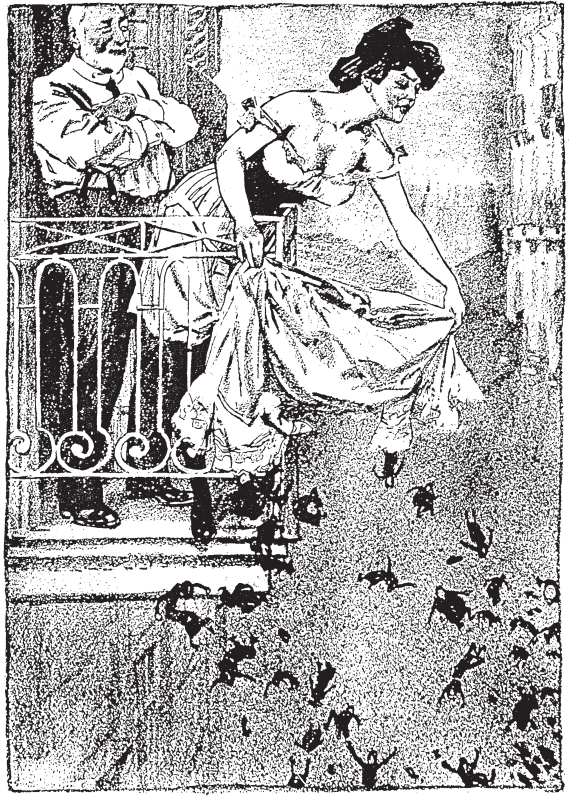

-¿Qué haces, República?

-Ya lo ves, Loubet: echo fuera a los parásitos de la Iglesia.

-Date prisa, que luego vendrá el pueblo a hacer lo mismo con nosotros, los parásitos del Estado.

Figura 12: Tierra y Libertad, 11 de marzo de 1904

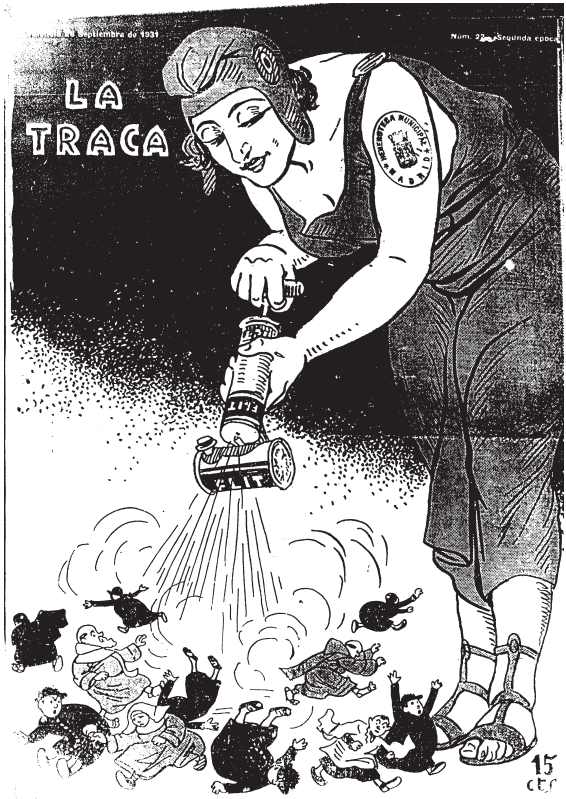

Creían los fanáticos españoles que el problema religioso derribaría a la República, y habrán visto que no; es simplemente una cuestión de higiene. Las hediondeces parasitarias con agua y jabón y un poco de Filt o Zotal, desaparecen.

Figura 13: La Traca, 26 de septiembre de 1931

La imaginería de las mujeres reproducida en los medios progresistas y revolucionarios no se agotaba en estas representaciones gráficas de carácter anticlerical cargadas de tintes antifeministas. El contrapunto más opuesto habría que situarlo en toda la iconografía que simbolizaba a la República mediante una figura femenina -que, en alguna ocasión, aparecía limpiando a España del clericalismo $0^{25}$ (Figura 12 y 13). A pesar de ello, el antifeminismo de base anticlerical parecía influir sobremanera en amplios sectores republicanos y obreros españoles del primer tercio del siglo XX. Constituía una componente fundamental en la construcción de su propia identidad como hombres republicanos, aliados del progreso y la razón, que no toleraban que alguien cuestionara su autoridad en su propia casa, y, mucho menos -según creían-, que otro hombre ejerciera

es el de Illion, Régine: Mujer, política y sindicalismo: Zaragoza, 1931-1936, Zaragoza, Fundación Fernando el Católico, 2002.

25. De la representación de España como mujer y de cómo ese símbolo, como otros, acabó republicanizándose, escribe FuENTES, Juan F.: «Iconografía de la idea de España en la segunda mitad del siglo XIX», Cercles. Revista d'Història Cultural, 5 (2002), pp. 8-25. 
mayor influencia que ellos sobre las mujeres de la familia. De todos modos, no era ésta una representación que afectara exclusivamente a la imagen que dichos hombres querían proyectar de sí mismos. Era un discurso que reflejaba claramente cómo la construcción de género que difundían sobre las mujeres adquirió hondas repercusiones públicas en el acceso de éstas al ejercicio del poder políti$\mathrm{co}$, en la medida en que sirvió para cuestionar el reconocimiento del derecho al sufragio que concedió la ciudadanía política a las mujeres en España. 